\title{
The activities of the Union for the Liberation of Ukraine in the Ottoman Empire during the first world war
}

\section{Hakan Kirimli}

To cite this article: Hakan Kirimli (1998) The activities of the Union for the Liberation of Ukraine in the Ottoman Empire during the first world war, Middle Eastern Studies, 34:4, 177-200, DOI: $10.1080 / 00263209808701248$

To link to this article: https://doi.org/10.1080/00263209808701248

曲 Published online: 06 Dec 2006.

Submit your article to this journal $\pi$

Џ Article views: 119 


\title{
The Activities of the Union for the Liberation of Ukraine in the Ottoman Empire during the First World War
}

\author{
HAKAN KIRIMLI
}

Relations between the Ottoman Empire and the Ukrainian people stretch back to the fifteenth century, though various Turkic peoples had been in close contact with the Slavic inhabitants of the lands which constitute the territory of contemporary Ukraine for at least a millennium. However, the Russian annexation of the Zaporozhian lands and other areas inhabited by the 'Little Russians', as well as the collapse of the Crimean Khanate and the consequent Ottoman withdrawal from the areas north of the Black Sea in the course of almost two centuries resulted by the nineteenth century in a sharp break in these relations. It was to take a long time until the beginning of the First World War when the Ottomans would be reminded of the particular identity of the native people of these lands through the Ukrainian national movement actively working via the channels of the Central Powers. The first nationalist organization aiming at the ultimate independence of Ukraine which included the Ottoman Empire in its sphere of activities was the 'Union for the Liberation of Ukraine' (Soyuz Vyzvolennya Ukrayiny).

Before the outbreak of the First World War, a number of Ukrainian revolutionaries and nationalists had taken refuge in the Austro-Hungarian Empire, particularly in the Western Ukrainian provinces of East Galicia and Bukovina. The Union for the Liberation of Ukraine (ULU) was formally founded in Lemberg (Lviv) in 4 August 1914 by the most prominent figures among these émigré politicians who cherished hopes of realizing their ideals after the eventual defeat of the Russian Empire. Though it kept close contact with the local (Western) Ukrainians, the ULU was an exclusive organization of the Ukrainians from the Russian Empire. The founders of the ULU were mostly socialists, and they included Andriy Zhuk, Oleksander SkoropysYoltukhivs'kyi, Volodymyr Kozlovs'kyi, Mariyan Basok-Melenevs'kyi, Oleksander Semeniv, Peter Bendzia, Mykola Zaliznyak (the leader of the Ukrainian Socialist Revolutionaries; he left the Union soon after and conducted his own activities independently), Dmytro Dontsov (who signed 
the founding declaration, but soon turned against the Union) and others. ${ }^{1}$ The ultimate aim of the Union for the Liberation of Ukraine was stated in its first declaration as follows: 'In this Union all shades of political interests are represented, and these have united in the claim for the political independence of the Ukrainian people. This Union sees the realization of its endeavors through the defeat of the Russian Empire by the United [Central] Powers. The independent Ukraine will be a constitutional and consequently a democratic monarchy, with one legislative body, having all civil, national and other rights and with its own national Church.' 2 To this end, the ULU was to work for winning over the Central Powers who were then fighting against the common enemy for the Ukrainian cause.

Thus, from the very start, the ULU cast its lot with the Central Powers. Based principally in the Austro-Hungarian Empire, apparently, the ULU managed to establish contacts with influencial circles in the Central Powers. The latter at least initially considered the Union for the Liberation of Ukraine and the Ukrainian national factor in general as a potentially useful card to be played against Russia, although both Austria-Hungary and Germany strictly refrained from officially including the formation of an independent Ukrainian state in their war aims. In this manner, the ULU usually received generous support for its activities from the Central Powers. The ULU's projects of large numbers of propagandistic publications, organizational activities, works among the Russian prisoners of war of Ukrainian origin, and even some military ventures were granted sponsorship by the Central Powers, especially by the Austro-Hungarian Empire, during the early months of the war.

The Ottoman Empire was not among the initial participants of the First World War. During the months following the outbreak of hostilities between the two blocs of European Powers, the Ottoman government hesitated to take sides. The recent Tripolitanian and Balkan wars which resulted in humiliating defeats and enormous territorial and other losses had devastated the country. The Committee of Union and Progress (İttihad ve Terakkî Komitesi) which had firmly acquired power since 1913 was looking forward to plenary and quick solutions to the long-accumulated chronic problems of the empire and to repair its prestige under new direction. This is not to say that the ruling Commitee of Union and Progress was unanimous in determining the ways to be chosen in internal and foreign policies; the co-existence of diametrically opposed views on several issues to do with the fate of the country, even among the highest echelons of the Committee, is well known. This indecision and conflicting opinions were clearly reflected in the wavering searches for the most suitable alliance with one of the two blocs of the European Powers. Indeed, either in line with the orientation and symphathies of an individual or a group of influential Union 
and Progress leaders, or due to the conjunction of circumstances or concerns, Ottoman government circles made approaches to almost all parties in order not to be on the losing side at the end of the Great War.

Still, especially after the outbreak of the First World War in August 1914, the Ottoman orientation toward the Central Powers was to become more and more evident. This, to a great extent, was to do with the proGerman stand of the powerful Minister of War, Enver Pasha, and his supporters, as well as the general frustration with the unsatisfactory responses of the Entente Powers to the previous Ottoman approaches toward them. One the most critical manifestations of this orientation was the secret Ottoman-German Alliance negotiated and signed between Enver Pasha and Hans Baron von Wangenheim, the German Ambassador in Istanbul, on 2 August $1914 .^{3}$ This alliance, which would ultimately lead to the Ottoman entry into the war on the side of the Central Powers, was kept strictly secret (only very few people were informed of it, even those in the Ottoman cabinet) and the Ottoman Empire maintained its formal neutrality for the following three months. Only a week after the secret OttomanGerman Alliance, two German men-of-war (Goeben and Breslau), hotly pursued by the British fleet, took refuge in the Dardanelles and soon the Ottoman government declared that they had been 'purchased' by Turkey. The chief engineer of this 'purchase' was Enver Pasha, who practically imposed it on the rest of the cabinet and the Sultan as a fait accompli.

It was during this increasingly pro-Central Powers neutrality of the Ottoman Empire that some joint military projects were secretly discussed and initiated between the Central Powers and the Ottoman political and military leaders. One of these ventures would involve plans for an Ottoman attack on the Russian Ukraine. On 16 August 1914, Enver Pasha called a secret meeting. Among the participants were von Wangenheim, Admiral Souchon (who came to Turkey as the commander of ex-German warship Goeben [now Yavuz] and then appointed Commander of the Ottoman Navy), General Liman von Sanders (the head of the German military mission in Turkey), German military and naval attachés, and several highranking Turkish officers. Apparently, the aim of the meeting was to discuss the possible actions of the Ottoman Empire in case it entered the war. The debate involved choosing between a possible attack on the Suez Canal and a land assault on the Odessa region. The latter plan was advocated by General Liman von Sanders, who thought that a Turkish landing on the coastal area between Odessa and Akkerman would bring considerable relief to the left wing of the Austro-Hungarian eastern front. Liman argued that since the Russian Black Sea Fleet did not seem to be very strong at that time and the Russian troops in the Odessa region were not well trained, such a daring operation could succeed. However, the success of the landed troops 
would depend on the prior defeat of the Russian Black Sea Fleet. To the dismay of Liman, the majority favoured an attack on the Suez Canal. ${ }^{5}$

Notwithstanding the rejection of Liman's plan, discussion of a possible operation in the Odessa region would appear to have continued for some time. Enver Pasha instructed his German chief of staff, General Bronsart von Schellendorff ('Bronsart Pasha'), to prepare a general plan for the movements of the Ottoman forces were the Ottoman Empire to join the war. In this plan, dated 20 August 1914, a landing operation in Odessa region was considered. The implementation of this project, however, was to be contingent on the prior achievement of naval supremacy in the Black Sea as well as the benevolent neutrality of Romania. Once realized, the timing of the operation would be determined according to the extent of the German and Austro-Hungarian offensive in Russia. Bronsart considered this the best possible military operation to be undertaken against Russia, one whose importance was such that it might even bring the European war to an end. ${ }^{6}$

On the other hand, Russia's impending capture of Lemberg led military circles in Vienna to look desperately for an operation to divert the Russians' attention elsewhere. Thus, on 1 September 1914, just two days before the fall of Lemberg, Joseph Pomiankowski, the Austro-Hungarian military attaché in Istanbul, received a cable from Vienna asking him to urge the Ottomans to organize a landing in Odessa. Pomiankowski had considered Liman's version of an operation against Odessa unfeasible, estimating that no less than two and half months would be needed to transport 50,000 troops from Istanbul to Odessa, during which time the Russians would be capable of destroying such a force without damaging their continuing campaign in Galicia. On that account, Pomiankowski cabled Vienna to the effect that the Turks did not intended to join the war at that time and that, at any rate, such a force was not available to them at that moment. ${ }^{7}$

Margrave Pallavicini, the Austro-Hungarian Ambassador in Istanbul, viewed the matter from a different perspective. As he explained in his cable to Count Berchtold, the Habsburg Foreign Minister, once the defence of the Çanakkale (Dardanelles) Strait was secured, the Ottoman Fleet should organize a sortie in the Black Sea. Such a show of force would cause Romania to enter the war on the side of the Central Powers. Thus, according to Pallavicini, such an outcome was more important than even the result of the landing in Odessa itself. ${ }^{8}$

Admiral Souchon, who in his new capacity as Commander of the Ottoman Navy was supposed to be in charge of amphibious operations, presented a report on the matter on 10 September 1914. He stated that a quick Ottoman naval victory over the Russian Black Sea Fleet was unlikely and the Ottoman naval forces needed better training if they were to undertake any such ventures in the Black Sea. Souchon claimed that it 
would be very difficult to contain the Russian fleet and that a landing operation in terrain which was so unsuitable and close to the bases of the Russian fleet would be risky. Were such an operation on the Odessa district to succeed, the landing would have to be made as near as possible to the Romanian border. ${ }^{9}$

Russians were already aware of the planned Ottoman-German naval operations on the Black Sea, including that of a landing in the Odessa region. Russian agents had managed to procure the contents of Pallavicini's above-mentioned telegram to Berchtold, and Giers, the Russian Ambassador in Istanbul, informed his government of its contents on 24 September 1914..$^{10}$ The Russians already knew about Enver Pasha's prerequisite of Ottoman naval supremacy in the Black Sea before any operations in that region could be launched. ${ }^{11}$ The Russians' knowledge of these plans must have been reinforced by other sources too. As Fahreddin Bey, the Ottoman chargé d'affaires in St Petersburg, cabled Istanbul on 25 October 1914, the Russian Foreign Minister Sergei D. Sazonov told a foreign military attaché that his government was aware of Ottoman plans for the Odessa landing supported by the guns of the Yavuz (formerly Goeben). ${ }^{12}$ The Ottoman entry into the First World War was to be triggered by the bombardment by the Ottoman fleet (including Yavuz and Midilli) of the Russian Black Sea ports of Odessa, Sevastopol (Akyar), Feodosiia (Kefe), and Novorossiisk on 29 October 1914. Within a few days of this 'Black Sea Affair', the Ottoman Empire was officially at war with the Entente in alliance with the Central Powers.

Before the outbreak of the Great War, no contacts between any Ukrainian nationalist organizations and Ottoman circles were known. True, there was an increasing interest among Ottoman intellectual circles in the nationalities problems within the Russian Empire thanks particularly to the presence and activities in Istanbul of several prominent Turkic émigré figures from the Russian Empire. Moreover, there were even renowned Russian revolutionaries, such as Israel Helphand (alias Parvus), who were in close contact with Ottoman intellectuals. Nonetheless, practically speaking, the 'Ukrainian national cause' was still unheard of even among the Turkish intelligentsia prior to the Great War.

Still, the Ottoman Empire seemed to be a promising field for the prospective activities of the ULU, which could also be to the advantage of the Central Powers. The Turkish public had always had a deep-seated animosity and revanchist attitude to Russia and the ever-present apprehension of the Russian threat had always been one of the most critical determinants of Ottoman foreign policy. Therefore, the Turkish public was expected to welcome designs or activities directed against the 'old enemy'. From the point of view of the ULU, the Ottoman Empire appeared to be a 
crucial ally in its designs for a future independent Ukraine. Not only did the ULU need new bases for its activities in a critical country such as Turkey where there was the possiblilty of serious public and governmental support for the Ukrainian cause, but the prospective Turkish military operations could also directly and concretely involve the Ukrainian factor in the continuing war.

Based initially in the Austro-Hungarian Empire, the ULU soon decided to send its emissaries to other countries which were considered to be potentially sympathetic or operationally useful, and, if possible, to establish representation there. To this end, ULU representatives were dispatched to Germany (Roman Smal-Stocki), Switzerland (Peter Bendzia), Turkey (Mariyan Basok-Melenevs'kyi) and Bulgaria (Lev Hankevych). ${ }^{13}$ BasokMelenevs'kyi, the ULU emissary to the Ottoman Empire, was a SocialDemocrat and the leader of the Ukrainian socialist group (Spilka) connected to the Russian Social Democratic Workers' Party. ${ }^{14}$ From Vienna, via Bucharest and Sofia he arrived in Istanbul in October, before the Ottomans entered the war. Since the Ottoman entry into the war was considered a foregone conclusion then, he looked to establishing contacts with Ottoman political and military circles. He soon travelled back to Vienna, and returned to Istanbul, where he planned to stay for a long time. In the meantime, his friend Lev Hankevych had settled in Sofia as the representative of the ULU in Bulgaria. ${ }^{15}$

It seems that Basok-Melenevs'kyi was successful in achieving access to a wide range of influential circles in Turkey. One of the first people he met in Istanbul was his old acquaintance from his membership in the Spilka group of Kiev, Parvus. The latter, long established in Istanbul and engaged in business, used his connections to help Basok-Melenevs'kyi organize his propaganda activities. He would also urge the latter to direct action inside Russia in order to incite a rebellion of the Ukrainian peasants. ${ }^{16}$ Possibly in return for his services, Parvus was to use his relations with BasokMelenevs'kyi and the ULU to acquire an Austro-Hungarian passport in November $1914 .{ }^{17}$ Parvus was not the only revolutionary whom BasokMelenevs'kyi met in Istanbul. He was also in close touch with the revolutionaries from the Caucasus, among whom was Trias, the Georgian revolutionary who had led the Georgian legion in the Iranian revolution. Trias had come to Vienna from Switzerland at the invitation of the ULU, and, having visited a number prisoner of war camps in Austria in search of reliable compatriots, travelled to Istanbul. In Vienna and Istanbul the ULU leaders discussed with Trias the possibilities of co-operation between their organizations. ${ }^{18}$

Almost certainly, Basok-Melenevs'kyi was familiar with the previous discussions of an Ottoman landing operation in the Odessa region through 
his contacts in Vienna and Istanbul. Such schemes must have appealed to him as they provided an excellent opportunity to extend ULU directly into Ukraine by virtue of the Turkish armed forces. He was quick to make acquaintances among the ruling Committee of Union and Progress, governmental and military officials, as well as the press, and it seems that he was received with sympathy wherever he went. According to one source, Ottoman statesmen promised to support the activities of the ULU in the Russian Ukraine as soon as the Turkish forces landed there. BasokMelenevs'kyi's work in Istanbul was steadily supported by the AustroHungarian and German diplomatic missions there. ${ }^{19}$ These diplomats of the Central Powers were doubtless of great service to him in his welcome reception by the Ottoman dignitaries.

It was through these channels that, as early as the beginning of October (or late September), the Ukrainian emissaries were involved in a plan considered by Major Süleyman Askerî Bey, the head of the 'Special Organization' (Teşkilat-1 Mahsusa, the Ottoman Secret Service) and a seasoned Union and Progress activist. This plan aimed at instigating revolts in the Caucasus and Kuban regions via sending an expedition by sea. For the initial needs of the operation the Central Powers had to capture a quantity of Russian arms. Therefore, in order to carry on the work of the plan, on 2 October 1914 Pallavicini asked Count Alexander von Hoyos, the Permanent Secretary of the Austro-Hungarian Foreign Office, about the trustworthiness of the Ukrainian emissaries. ${ }^{20}$ To this, Hoyos replied, with a request to inform Süleyman Askerî Bey that the Ukrainian emissaries were considered fully trustworthy and co-operation with them was recommended by the Austro-Hungarian government. ${ }^{21}$ With his telegram on 9 October 1914 Hoyos informed Pallavicini that the Ukrainian emissaries also planned to incite the Russian Black Sea Fleet to revolt. Turkey would assist such a mutiny by promising to receive mutinous ships in Istanbul and arrange their eventual purchase by the Ottoman government. ${ }^{22}$

It is noteworthy that at the time these plans were being considered the Ottoman Empire had not yet entered the war. The Austro-Hungarians realized the importance of the Ottomans entering the war on the side of the Central Powers. Ottoman military operations on the northern shores of the Black Sea might divert Russia's attention from the critical eastern front of the Central Powers, including hard-pressed Austria-Hungary. The inclusion of Russian Ukraine in the operations, and the partial involvement of the Union for the Liberation of Ukraine, would not only be militarily advantageous but, more importantly, might incite a national uprising among the Ukrainian population in the area. The military feasibility of such projects aside, Ottoman engagement with them could facilitate the participation of the hitherto non-belligerent Ottoman Empire in the war. 
Some German diplomats in Istanbul were particularly interested in the subversive consequences of prospective revolutionary or nationalist actions in the rear of the Russian armies. Dr Max Zimmer and his associate Heinrich Nebel had been charged with organizing revolutionary movements in Russia. Zimmer was planning to incite a large-scale revolutionary insurgency in the western Caucasus. He was already working in close cooperation with the Ottoman secret war cabinet led by the like-minded Enver Pasha. To this end, Zimmer sought to establish contacts with dissident groups from the Russian Empire. When he was introduced to BasokMelenevs'kyi in Vienna in October 1914, he came to the conclusion that the ULU and its agents in the Caucasus could be of use to his designs. Upon the return of both men to Istanbul, they, together with Parvus, began to mull over the project of an uprising by the Caucasian mountaineers as well as the Kuban Cossacks and the Ukrainians. ${ }^{23}$ In fact, there was another plan, involving the Georgian revolutionary Trias, to provoke an uprising in the Caucasus with a Turko-German expeditionary force under the command of the Austrian Colonel Count Stanislaw Szeptycki. Basok-Melenevs'kyi must have tried to combine this plan with his own, and to organize a Turkish landing on the shores of the Black Sea, preferably in the Odessa region. ${ }^{24}$

The prospects of participating in the landing on the Ukrainian Black Sea coast together with the Ottoman expeditionary forces prompted BasokMelenevs'kyi to enlarge the ULU mission in Istanbul. Thus, he established a working group (headed by himself) of nine persons consisting of three ULU members and six associates. He also considered selecting others from among the Russian prisoners of war. The propagandists of the ULU could have been dispatched to Ukraine from this base in Istanbul. ${ }^{25}$

By November 1914 (when Turkey entered the war) the plan of landing a Turkish expeditionary force involving the ULU crystallized and came to be known among the circles of the Central Powers as the "Constantinople Action' [Konstantinopler Aktion]. The final details of the 'Constantinople Action' were presented to the Austro-Hungarian Foreign Office during the first week of November by Basok-Melenevs'kyi, who then travelled to Vienna. In his private letter to Colonel Hranilovic of 8 November 1914, Count Hoyos summarized the plan and his opinion of it. As explained in this letter, the emissaries of the ULU had discussed with Enver Pasha's representatives in Istanbul Turkish-Ukrainian military co-operation in order to instigate a revolutionary movement in Ukraine by landing on the Russian Black Sea coast a small Ukrainian detachment protected by strong Turkish forces. In conformity with the discussions in Istanbul, the ULU requested from the Austro-Hungarian government an expeditionary corps of 500 Ukrainians, composed of 400 Austro-Hungarian Ukrainian legionaries and 100 Ukrainians to be selected from among the Russian prisoners of war. 
Hoyos asked Hranilovic to seek the approval of the Army Supreme Command to implement this plan. Then Colonel Fischer in Bukovina would be entrusted with choosing from among the personnel of the Ukrainian Riflemen [Sichovi Stril'tsi] the 400 legionaries who would necessarily be all volunteers. As for the 100 volunteers from among the prisoners of war, Colonel von Steinitz would authorize their selection. With this in mind, Hoyos suggested establishing a separate prisoner of war camp for the purpose of conducting revolutionary propaganda where suitable elements for the expedition would be selected. An officer of the Ukrainian Riflemen, as well as a representative of the ULU would also go to Bukovina to help select volunteers. ${ }^{26}$

As there was no direct land route between the Central Powers and the Ottoman Empire then (Bulgaria and Romania were still neutral), there was the problem of transporting these volunteers without creating diplomatic complications. The solution proposed by Hoyos was to send them via Romania in civilian clothing and in separate groups of 25 men in each train. The Austro-Hungarians would cover the costs of clothing and travel expenses, while their uniforms and equipment would be supplied by the Ottoman Empire when they arrived in Istanbul. Since the Turkish authorities expected to establish Turkish naval supremacy in the Black Sea within two to three weeks, the expeditionary corps would have to arrive in Istanbul by then. Count Hoyos' expectations from this enterprise were not great, but he still harboured the opinion that the show of courage involved would induce a revolution in the Caucasian border regions of Ukraine which might tie down the Russian forces. He also thought that the outbreak of such revolutionary movements in Russia might help to mobilize Romania, which was apprehensive of the Russian might, on the side of the Central Powers. ${ }^{27}$ Accordingly, on 13 November 1914 Hoyos wrote to Colonel Fischer, the Gendarmerie Commander of the District of Bukovina, to brief him on the details of the undertaking. He informed Fischer that the selection of 100 volunteers from among the prisoners of war in the camp in Freistadt (Upper Austria) had been entrusted to a delegate of the ULU. The representatives of the ULU and the Ukrainian National Council would also participate in the recruitment of volunteers from the Ukrainian Riflemen under Fischer's jurisdiction. $^{28}$

While Basok-Melenevs'kyi and Zimmer were in Vienna, they discussed the plan with Hoyos in detail. According to this, the landing was to be in the Kuban region with a Turkish expeditionary force of 50,000, supplemented by the above-mentioned 500 Ukrainian volunteers. The primary aim would be to provoke an uprising among the Kabardians and Kuban Cossacks. Zimmer himself would also take part in the venture, and it was hoped that the presence of the Ukrainian legionaries would be of particular operational 
use in stirring unrest among their ethnic kinsmen, the Kuban Cossacks. If the operation were a success, a nucleus of the Ukrainian state could be established there, and the Ukrainian movement could be expected to spread toward the west. However, all these plans were yet to be cleared by Turkey. Upon their arrival in Istanbul, Basok-Melenevs'kyi and Zimmer would seek the approval of Liman von Sanders and Enver Pasha. To obtain this, Hoyos asked Pallavicini to contact Enver Pasha and von Sanders. In fact, as Hoyos stated, the Austro-Hungarians preferred a landing in Odessa over an expedition in North Caucasus. The latter option would be acceptable only in the case of a complete abandonment of the Odessa action, or if both operations could be carried out simultaneously. ${ }^{29}$ These were, however, not Hoyos' only reservations about the 'Constantinople Action.' He strongly favoured entrusting command of the Turko-Ukrainian expedition to the Austrian General Staff officer Count Szeptycki. For not only would the presence of an Austrian commander have a bearing on further developments in Ukraine (or rather the Kuban region), but it would also demonstrate that his country was not totally reliant on the Germans. Although Hoyos was sceptical about the actions of Germans like Zimmer, who, according to Hoyos, tended to employ incorrect and overhasty methods, he still refrained from outright rejection of the German plans. Such an attitude might have created ill-feeling between the allies, and might have given an awkward impression about the Austrians, and might have made the Germans think that they should do everything alone. Therefore, Hoyos argued, unless their demands were outrageous, the Germans should be listened to in a friendly spirit and given encouragement in order to keep them working for the common cause. After all, Hoyos also believed that only inner unrest could cause the Russian colossus to falter. ${ }^{30}$ Apparently, after exerting his influence, Hoyos succeeded in winning the approval of the AustroHungarian Army Supreme Commander for the 'Constantinople Action'. The Army Supreme Commander also accepted Hoyos' idea of entrusting the command of the action to Count Szeptycki, provided that he be given unrestricted command over the whole expeditionary corps. ${ }^{31}$

Notwithstanding the euphoria of Basok-Melenevs'kyi, Zimmer, Nebel and the qualified enthusiasm of Hoyos, it soon became apparent that their optimism was premature: Turkey, which was supposed to bear the brunt of the operation, seemed to demur, to say the least. Pallavicini's telegram to Hoyos on 16 November 1914 made it clear that, although Enver Pasha agreed in principle with the idea of landing an expeditionary corps in the Northern Caucasus, this could only occur if control of the Black Sea could be fully secured, and that temporary control would not do. If the 500 Ukrainian legionaries cared to undertake the operation alone, Enver Pasha would be ready to take them to the Black Sea and have them landed in a 
designated spot; but once landed they would be on their own [auf eigene Faust operieren]. General Liman von Sanders was of a similar opinion, that landing a large force before securing total control of the Black Sea would be impractical. Even Pallavicini thought that Turkey should not commit itself to the operation until the position of the Bulgarians became absolutely certain. ${ }^{32}$

Turkey's obvious reluctance to embark on such a daring venture, which entailed so much cost and risk and promised only dubious rewards, put paid to the plan, at least as it had been conceived. Now Hoyos also had to acknowledge that the success of the 'Constantinople Action' depended on Russian Black Sea Fleet being put out of action. Therefore, he decided not to send any Ukrainian legionaries to Istanbul before a decision had been reached on the operation, since keeping them there without any clear duty would serve no purpose ${ }^{33}$ Hoyos reiterated these decisions to Pallavicini and felt it necessary to explicate his previous commitment to the plan, in a somewhat apologetic fashion. He explained that the idea of an expedition had come from Dr Zimmer, who in Vienna had declared that only Colonel of the General Staff Count Szeptycki was suited to lead such an expedition, in which the Circassians and the Kuban Cossacks would join with the landing Turkish troops. At the same time, 'Achari Beg' [Süleyman Askerî Bey] had asked the ULU to dispatch 500 Austrian Ukrainians to Istanbul, where they would be armed and uniformed by the Turks and form the Ukrainian corps of the expedition to the Caucasus. Hoyos had put these plans before the Austro-Hungarian Army Supreme Command and had acquired its consent, provided that the Turkish expedition to the Caucasus were equipped adequately and its command offered to Count Szeptycki with unrestricted power. In his support of Count Szeptycki, Hoyos had thought that the prestige of Austro-Hungary would rise if an Austro-Hungarian officer played a leading role in a Turkish expedition. The 500 Ukrainian legionaries could still be dispatched to Istanbul, but Hoyos would not sanction this without a guarantee that they would be fed and supplied by the Turks and would join a larger Turkish landing force either to Odessa or to the Caucasus. Enver Pasha's proposal to having them land on Kuban was unacceptable to Hoyos. He also had doubts about the commitment of the Ukrainians in these regions and felt that they could be more useful in other areas. The Ukrainian Riflemen (Sichovi Stril'tsi) consisted almost entirely of intelligentsia (students and teachers), who would be needed in Podolia. Hoyos wrote:

I share your opinion that one should not strive for too much and should be content with a modest benefit. Unfortunately, the hopes of public opinion especially in Germany are very much excited, and 
expectations are carried too far especially as far as England is concerned, and the people seem to be almost willing to venture for the great success of Imperium Mundi. All this is beyond the realpolitisch possibilities, and I share your opinion that we can be very much satisfied if, while maintaining our integrity we and Germany remain the masters in Constantinople. ${ }^{34}$

In the meantime, the Austro-Hungarian Army Supreme Command had already recognized the impracticable nature of the 'Constantinople Action' through its own intelligence sources. Pomiankowski, the Austro-Hungarian military attache in Istanbul, reported to the Army Supreme Command that the 'plan was totally unknown to the Ottoman government'. His report also included the information that any commitment of the Turkish troops was out of the question. ${ }^{35}$ As he stated in his memoirs, Pomiankowski not only had considered the plan unrealistic, but had had difficulty in convincing himself that Vienna had indeed sanctioned such an adventure. For Pomiankowski, the Turks would never accept the sacrifice of 50,000 of their troops under a foreign commander, totally ignoring the incapacity of the Ottoman transportation fleet. Moreover, the Kuban Cossacks, though ethnically related to the Ukrainians, were among the most loyal subjects of the Tsar and they were the very people who had been settled on the lands grabbed from the native Muslims. Not surprisingly they were justifiably regarded as the greatest foes of the Muslims. In view of all this, the Ottoman authorities and the Kuban Cossacks would be most unlikely to accept a plan of an alliance. Pomiankowski cabled Vienna to the effect that even proposing such a plan to the Turks might create a very undesirable reaction in Ottoman circles. ${ }^{36}$

In view of these disappointing developments, on 19 November 1914 the Army Supreme Command had to reverse its recent decision to commission Count Szeptycki to command the operation. ${ }^{37}$ As it became clear that Turkish co-operation in the plan was not realistic in the foreseeable future, the selection of volunteers from among the Ukrainian Riflemen was also cancelled. After all, the Ukrainian Riflemen were rendering very good service in the Carpathian passes and the extraction of 500 men from their ranks for a mission which might never take place would be unwise..$^{38}$

Thus, the 'Constantinople Action' remained a unilateral and premature enthusiasm among some ULU members and some officials of the Central Powers. The latter, however, had already gone too far to drop the matter abruptly. This was especially the case for Hoyos. ${ }^{39}$ Quite possibly to save face, Hoyos attempted to extract at least some diplomatic concessions from the Turks on the Ukrainian issue. So, he instructed Pallavicini to notify the Ottoman Foreign and War Ministers that their principal goal in the war was 
the sustained weakening of Russia and that in the event of victory they would initiate the building of a Ukrainian state independent from Russia. The existence of such a state would also greatly suit the interests of Turkey, since Russia's presence on the Black Sea would thereby be dealt a significant, if not mortal, blow. With this goal in mind, all attempts to liberate Ukraine and especially the purposeful activities of the ULU, whose representative in Istanbul was Basok-Melenevs'kyi, had to be strongly supported. ${ }^{40}$

These statements signalled official recognition of the inglorious fate of the 'Constantinople Action'. Many of the officials of the Central Powers (possibly including Hoyos) involved must have realized from the very beginning that such a daring venture was neither feasible nor justifiable. This notwithstanding, at least in the short run, an Ottoman operation somewhere closer to the actual battlegrounds of the Central Powers, especially those of the Austro-Hungarians would have had the immediate effect of relieving the latter's burden to some extent. This would also have had the effect of inflaming revolutionary and nationalist subversion at the rear of Russia with the minimum initial cost to the Germanic Powers.

On the other hand, by committing itself to such an operation, allocating many troops $(50,000 \mathrm{men})$ in a not-so-directly-relevant place far from supply lines, at a time when the immediate defence of other areas (i.e. the Straits, Black Sea, and the Caucasian front, not to mention extremely wide lines of other fronts facing the British and French) was of great urgency, Turkey would have taken an unnecessary gamble. Despite some early talks about landing operations, the actual developments of the Ottoman war from the very beginning of the hostilities were to indicate most clearly that anything of the sort would be out of question. The Ottoman navy could not achieve indisputable supremacy in the Black Sea (until the Russian Revolution), and the Russian Black Sea Fleet continued to be a very serious threat. The urgent transportation of Turkish soldiers and supplies to the critical Caucasian front by the Black Sea could be realized only at great risk and only with the commitment of the best ships in the Ottoman fleet, whose commanders often objected to troop transportation in such numbers. Added to which, the Russian navy would impede the transportation of troops and supplies. Moreover, the calamitous situation on the Caucasian front which followed the Sarıamıs disaster at the end of December 1914, as well as the subsequent military engagements on the Mesopotamian, Suez and Dardanelles fronts throughout 1915 were more than enough to inhibit any adventures like the 'Constantinople Action'. ${ }^{41}$

It is quite possible that the ULU representatives and German diplomats in Istanbul had interpreted the polite reception and expressions of solidarity they had received from Ottoman officials (most of whom must have been 
subordinates rather than the decision-makers) in an overoptimistic way. There is little evidence to indicate that the 'Constantinople Action' as contemplated by some diplomats and officials of the Central Powers and the ULU had ever been seriously considered by the Ottomans, who at the time had more urgent concerns. However, a landing operation, though only remotely reminiscent of the 'Constantinople Action', indeed took place during the first week of December 1914. This plan (which seemed to be inspired by the early discussions of landing a Turkish force on the shores of Odessa or Akkerman) involved landing 24 Turkish cavalrymen, who spoke Russian and wore Russian uniforms, in Russian Bessarabia. This small force was supposed to reach Romanian territory after destroying the Bender railway and some bridges. As planned, the Ottoman steamboat Zafer which carried Russian colours and was protected by the light cruiser Midilli (formerly Breslau) landed these 24 soldiers, together with their mounts, on Serpent Island to the south of Sulina, at the mouth of the Danube River, on 6 December 1914. Nevertheless, the platoon was soon discovered and captured by the Russians. ${ }^{42}$ There is no indication that this abortive attempt was in any way related to the original plan of the 'Constantinople Action' or to the Ukrainians.

Although by the third week of November 1914, the 'Constantinople Action' had been abandoned, the ULU continued to hope to dispatch its propagandists to Ukraine via the Turkish forces. As late as mid-December 1914 the ULU leaders, though with less enthusiasm, were still entertaining the realization of the 'Constantinople Action'. According to them, if any success was to be expected from the operation, it should necessarily be in harmony with the Ukrainian national aspirations. The intelligence gathering and diplomatic contacts of the ULU had laid safe and promising groundwork for the action which not even the most effective secret service could provide. The key for the success of the action lay in the Ukrainians' accepting the enemies of Russia as their friends, and, therefore, the success of the ULU was the prerequisite of the action..$^{43}$ As their hopes of ever realizing the original plan waned, the ULU leaders must have desired to obtain the maximum political gain from their efforts. Such gains could be made were some or all of the Central Powers to declare that they would include the independence of Ukraine in their proclaimed war aims and thereby their official and unequivocal commitment to their cause. Of course, the leaders also wanted to see the ULU in a much stronger and secure position vis- $\grave{a}$-vis the Central Powers. To this end, the ULU leaders stressed that the Central Powers had to support their ultimate aim to establish an independent Ukrainian state. Only in this way could any misgivings about making cannon fodder of the Ukrainian volunteers or abandoning the Ukrainians to their fate after the war be eliminated. ${ }^{44}$ 
In fact, Austro-Hungary's reservations about the 'Constantinople Action' also coincided with their disenchantment with the activities of the ULU. The frustration of those Austro-Hungarian officials who were involved in the futile engagements of the 'Constantinople Action' might have played a role in this changing attitude. According to Fedyshyn, the Ukrainian movement could be of value to the Habsburg Empire only if Austro-Hungarian troops indeed marched into Russian Ukraine, but at the time the opposite was the case. The Austro-Hungarian government would also not like to see the rise of Ukrainian nationalism in Galicia while promoting revolution in Russian Ukraine. Moreover, the Austrians began to rely increasingly on pro-Polish policies, which would lead them to distance themselves from the Ukrainians, whose national territorial aspirations conflicted with those of the Poles. ${ }^{45}$ Thus, on 17 December 1914 Vienna reduced the annual allowance to the ULU by half, and imposed serious restrictions on its activities. Furthermore, the ULU was advised to transfer its headquarters to either Istanbul or Sofia.$^{46}$ The ULU leaders were not at all comfortable with the idea of moving their centre of activities to Istanbul. One of the ULU leaders, Skoropys-Yoltukhivs'kyi, argued that such a hasty transfer from Vienna to Istanbul would disappoint the Ukrainian people who hitherto considered the Austrians as their liberators and who would gain the impression that the Austrians were ousting their brothers and would resent their previous symphathies toward Austro-Hungary. Not all the nationallyconscious elements in Ukraine could understand the motives behind such a move, and lend their support in the future. The transfer of the ULU headquarters from Vienna, which had been a very natural centre for Ukrainians, to Istanbul, with which Ukrainians had neither cultural nor national links, would be anathema to Ukrainian intellectuals. Were it to happen, the Russian press could easily impose the idea that the ULU was a group of traitors ready to be sold off to the highest bidder, first to the Germans, and then to the Turks. ${ }^{47}$ Skoropys-Yoltukhivs'kyi also claimed that, although the Kuban Cossacks in the Russian army objected to fighting against their brethren within the Austro-Hungarian army on the Galician front, they were not considering every enemy of Russia as their friends yet and stated that they were ready to fight against the real enemy, i.e. the Turks, to defend their country ${ }^{48}$ Eventually, the transfer of the ULU's headquarters to Istanbul did not take place. Though the ULU's relations with the AustroHungarian government improved and it was even invited to remain in Vienna for some months, in spring 1915 its headquarters were finally moved to Berlin. ${ }^{49}$

The failure of the 'Constantinople Action' was certainly a matter of frustration for the ULU. Nonetheless, Turkey was still a critical country even without this project. Therefore, the ULU mission in Istanbul tried to 
make the best use of this important base. Probably with the co-operation of the Ottoman authorities, at least one ULU 'organizer' from Istanbul infiltrated Russian Ukraine in November 1914, and the dispatch of others was under consideration. ${ }^{50}$ The activities of the ULU mission in Istanbul on matters of propaganda, however, proved to be much more effective than their plans for military action.

In this respect, relations between ULU representatives and Ottoman statesmen were of special significance. On 9 November 1914 the representatives of the ULU, Mariyan Basok-Melenevs'kyi, Dr Stefan Baran and Longin Tsehels'kyi, were received by Talât Bey (later Pasha and Grand Vizier), the then Ottoman Minister of Interior Affairs and the strongest political leader of the ruling Committee/Party of Union and Progress..$^{s 1}$ In this meeting Talât Bey promised to support Ukrainian efforts to establish an independent state especially during the peace conference. He also stressed that an independent Ukrainian state on the shores of the Black Sea would be in Turkey's interests. ${ }^{52}$ Talât Bey's statements were published in Jeune Turc (24 November 1914) and thus made public. Talât Bey wrote to the effect that the Porte, Berlin and Vienna had recognized that Ukraine had to be removed from Russian domination, and that the Ottoman government promised the Ukrainian people to support the establishment of an independent state in the event of Russia's defeat. ${ }^{53}$ The ULU considered Talât Bey's statements very significant, the first public commitment on the part of one of the Central Powers (which could also be expounded in a way to cover others) to the independence of Ukraine if the war ended in victory. This development certainly attracted attention in Russia too. On 26 November 1914 the Petersburg Telegraf Agency published the news as it appeared in the Ottoman press, and leading Russian papers, such as Utro Rossii, Novoe Vremia, Rech, Birzhevyie Vedomosti, and others carried the story. ${ }^{54}$

The ULU mission in Istanbul was particularly keen on propagating its activities and goals through the Turkish press and its own publications. Basok-Melenevs'kyi worked hard to establish contacts in the Turkish press, and thanks to his efforts several articles and news items about Ukraine began to appear in Istanbul papers before Turkey entered the war. ${ }^{55}$ It should be noted that before the First World War Ukraine as a political concept, let alone its cause for independence, was virtually unknown to the Ottoman press circles. Therefore, whatever began to appear in these newspapers from October 1914 on were the first pieces of information about the subject Ottoman journalists and their readers ever encountered. The news items in the Istanbul press about the ULU and the Ukraine, particularly before the Ottomans joined the war, were observed with pleasure by the diplomatic missions of Central Powers in Istanbul. When Tasfir-i Efkâr (Tasvîr-i 
Efkâr), an influential daily, printed the 'Appeal of the Union for the Liberation of Ukraine to the Turkish Nation', ${ }^{56}$ the Austro-Hungarian Embassy in Istanbul was elated, as it considered this an indication of escalating anti-Russian sentiment among the Turkish press as well as in the Muslim population. ${ }^{57}$ Such pieces about Ukraine, often containing questionable information of a purely propagandistic nature, continued to appear in the Istanbul press after 1914. A typical example appeared in the semi-official organ of the Committee of Union and Progress, Tanin, on 13 December 1914, with the title 'Revolutionary Movements in Ukraine Are Progressing'. In this news item originating from Berlin it was claimed that, although the Russian government had secretly arrested and banished the leaders of the Ukrainian movement and all the Ukraine's press and societies had been closed down, the Ukrainian revolution was progressing every day. ${ }^{58}$ Another news item in Tanin informed its readers about a congress of the Ukrainians residing in the United States. According to the information, in the congress which took place in New York, the participants expressed their hopes for the disintegration of the Russian Empire, stated their gratitude to the Habsburg Emperor, 'having taken into consideration the liberties which the four million Ukrainians living in the Austro-Hungarian Empire enjoyed'..$^{99}$

The ULU itself was engaged in some publishing activities in Istanbul. First, appeals were printed for the Russian prisoners of war, in both Ukrainian [Soldate - ozernysy] and Russian [Soldatam Russkoi Armii] languages, 25,000 copies for each language..$^{60}$ The 'Appeal of the Union for the Liberation of Ukraine to the Turkish Nation' was also printed in the form of leaflets. ${ }^{61}$ In the report on the activities of the ULU until mid-December 1914 it was stated that Longin Tsehels'kyi's booklet entitled 'Russia Oppressor of Nations' was published in Turkish. ${ }^{62}$ The same document also mentions the ULU's intention to publish Turkish translations of Longin Tsehels'kyi's 'How Russia Saved Ukraine?', ${ }^{63}$ Lev Hankevych's 'Turkey in the Context of War', a booklet entitled 'Not the Liberator, But the Oppressor of Peoples', ${ }^{64}$ and a brochure by Dr Rudnyts'kyi. ${ }^{65}$ It seems that none of these was published. Nevertheless, the ULU succeeded in publishing an important collection of articles and documents in Turkish, in 1915. This book, entitled Ukrayna, Rusya ve Türkiye (Makaleler Mecmuast) [Ukraine, Russia and Turkey (Collection of Articles)], was the first book in the Turkish language about modern Ukraine and Ukrainian nationalist and revolutionary movements. ${ }^{66}$

The book consisted of eight articles and documents: Longin Tsehels'kyi, 'Ukraine and Turkey'; Mykhailo Hrushevs'kyi, 'A Glance at Ukrainian History in Retrospect'; Volodymyr Doroshenko, 'Political Parties in Russian Ukraine'; Mariyan Melenevs'kyi, 'Cultural Movements of the 
Ukrainians'; Andriy Zhuk, 'Russian Ukraine'; 'Appeal of the Union for the Liberation of Ukraine to the Turkish Nation'; 'To the European Public'; and 'Program of the Union for the Liberation of Ukraine'. In the preface, written in December 1914, the editors drew an analogy between the activities and aims of the 'Young Turks' in the past and those of the contemporary Union for the Liberation of Ukraine. They also pointed out the historical ties between the Turks and Ukrainians, and their hopes for the imminent collapse of the 'rotten Russian Empire', with the assistance of the Ottoman Empire. ${ }^{67}$

Among the historical and cultural articles which were originally translated from other publications, Tsehels'kyi's article stood out as the one written specifically for the Turkish reader. Having succinctly surveyed Ottoman-Ukrainian relations in history, Tsehels'kyi wrote:

The reasons which lead Turkey to consider Ukraine as a defence ditch against Russia in the seventeenth and eighteenth centuries prevail today even more strongly than in the past, as in our times Russia presents such a threat to the Balkans and the Ottoman Empire. Russia's advance to the Straits and Istanbul can come to an end only if either the Straits and Istanbul fall to the hands of the Russians, or the Russians are pushed northwards behind the Ukrainian boundaries. The formation, or rather the re-establishment, of the Ukrainian government, in accord with the designs of the [seventeenth century] Grand Vizier Köprülü Mehmed Pasha, is a direct requirement of Turkey's interests. ${ }^{68}$

In the 'Appeal of the Union for the Liberation of Ukraine to the Turkish Nation', special attention was paid to emphasize the Russian threat to Turkey and to dissociate Ukrainians from the 'fake pan-Slavism of Russia' which had created havoc for the Ottomans in the Balkans. The 'Appeal' also struck another sensitive chord in Turkey, that is, the concern over the fate of Muslims in the Russian Empire. It asserted that while millions of Muslims in the Russian Empire were suffering, it was imperative for the Ottoman Empire to join the fight against Russia, and together with their coreligionist Muslims, Ukrainians and other subjugated peoples of Russia too would welcome the Ottomans. ${ }^{69}$ As the Turks and Ukrainians had allied themselves against the common enemy (i.e. Russia) during the times of Hetmans Petro Doroshenko and Filip Orlik, they should renew this alliance; and when Russia was rolled back to its natural borders of the Moscovite world, the free Ukrainian nation would live in alliance with the Ottoman Empire. ${ }^{70}$

There is little doubt that these approaches of the ULU were warmly received in Istanbul, as they reflected the prevailing anti-Russian and nationalistic mood. Nevertheless, the catastrophic progress of the Ottoman 
military campaigns against the Russian armies soon replaced the initial grandiose hopes of conquest, with serious concerns about recovering great losses, if not finding ways to preserve the very existence of the Ottoman Empire. Under these negative circumstances, both the representatives of the Central Powers and the ULU must have realized that there was little the ULU could expect to accomplish in Istanbul in regard to its initial grandiose hopes and projects. After all, especially after the ULU headquarters were transferred to Berlin, Germany became the pivotal venue of Ukrainian nationalist activities, as by then this country's performance in the war seemed to be the main determinant in the future of the Ukraine. Thus, apparently, Basok-Melenevs'kyi's activities in Istanbul turned rather to lobbying work among the diplomatic corps of the Central Powers, than seeking ways of doing business directly with the Ottoman government. It is known that in May 1915 he visited the German and Austro-Hungarian ambassadors in Istanbul to enquire whether the Central Powers, in view of the progressing spring offensive of their eastern armies, would consider the establishment of a Ukrainian provisional government in the would-beoccupied Ukrainian lands. He asserted that if civil administration were entrusted to such a Ukrainian government and if its legitimacy were recognized even on a portion of Ukraine which could be conquered, this would created a genuine basis for the eventual state-building over the rest of the Ukraine. ${ }^{71}$

Although, in the face of the available evidence, it seems that after 1915 the activities of the ULU in Turkey lost their initial euphoria, this, by no means suggests that the relations between the Ottoman Empire and Ukrainian nationalists were severed. In fact, the energetic Ottoman intelligence service, the 'Special Organizition' (Teşkilat-1 Mahsûsa) or the 'Directorate for Eastern Affairs' (Umûr-u Şarkiyye Müdîriyeti), was always keen on maintaining close relations with, if not directly sponsoring, nationalist movements pertaining to the imperial territories of the enemy powers, especially those of the Russian Empire. Thus, a certain group of Ukrainian nationalists was allowed to live in Istanbul under the auspices of the 'Special Organization'. This group of Ukrainian nationalists is mentioned in contemporary Ottoman documents as the "Ukrainian Committee' and, for all likelihood, they belonged to the ULU. ${ }^{72}$ The evidence suggests that they worked hand in glove with the 'Special Organization', which offered them certain support even beyond the Ottoman boundaries. In this manner, when they needed to travel abroad, they were readily given Ottoman passports. ${ }^{73}$ Apparently, such members of the 'Ukrainian Committee' continued to reside in Istanbul at least until the first months of 1918 when they were sent to their country which was then experiencing the turbulent process of the newly declared independence. ${ }^{74}$ 
Before the Russian revolutions of 1917 and the consequent Ukrainian independence, one more event concerning the Ottoman military and the Ukrainians deserves to be mentioned. In 1916 a large number of Ottoman troops was sent to the Galician front to relieve their allies. This was the first actual appearance of the Ottoman military in a land where Ukrainians lived. The Ottoman troops, whose performance in eastern Galicia were admittedly praised, fought there next to the volunteer Ukrainian Riflemen units of the Austro-Hungarian army. ${ }^{75}$ We are not aware of any role the ULU played in establishing contact between the Ottoman troops and the Ukrainian Riflemen there.

The relations between the ULU and the Ottoman governmental institutions and public during the First World War constitute the first instance when the 'Ukrainian national factor' was brought to the attention of the latter and was considered in its foreign policy. Certainly, the activities of the ULU were made possible only within a much broader context of the wartime policies and post-war considerations of the Central Powers as regards the Russian Empire. It was thanks to the German and AustroHungarian sponsorship that the ULU was able to operate and find itself in a position to play a crucial role in the future of Ukraine. Similarly, it was again these Central European Powers who introduced the ULU to the Ottomans. As they viewed the ULU primarily as a useful device with which to effect Ottoman policy (before and after the Ottoman entry to the war), Ottoman officials appreciated the intrinsic value of the Ukrainian factor for the future of their own state. To the dismay of both the Germanic empires and the ULU, their initial ambitious, if half-baked, schemes involving the Ottoman Empire proved to be utterly impracticable. It appears that none of the contemplated military operations concerning a joint action of Turkish soldiers and Ukrainian volunteers could be realized. This is not to say that the ULU was left empty-handed in its relations with the Ottomans. The Ottomans too extended their sponsorship to the ULU, and supported its activities clandestinely. On the other hand, the ULU found means to reach out to at least some segments of the Ottoman intellectual public, and received a warm and symphatetic response. The impression created by the ULU in Turkey about Ukraine must have contributed positively to the development of diplomatic relations between the Ottoman Empire and the independent Ukrainian People's Republic following the Treaty of BrestLitovsk in 1918. 


\section{NOTES}

1. Andriy Zhuk, 'Soyuz Vyzvolennya Ukrayiny', Pamyatkova knizhka soyuza vyzvolennya Ukrayiny. Kalendar' na 1917 rik (Vienna, 1917), pp.367-8; A. Zhukovs'kyi, 'Soyuz Vyzvolennya Ukrayiny', Entsyklopediia Ukrayinoznavstva (Munich, 1976), Vol.II/8, pp.2971-72; Roman Smal-Stocki, "Actions of "Union for the Liberation of Ukraine" during World War I', The Ukrainian Quarterly, Vol.XV, No.2, p.170; Oleh S. Fedyshyn, Germany's Drive to the East and the Ukrainian Revolution, 1917-1918 (New Brunswick, NJ, 1971), pp.30-1.

2. Der Bund zur Befreiung der Ukraina (Sonderabdruck aus der Nummer I der 'Ukrainischen Nachrichten') (Vienna, 1914).

3. As a matter of fact, the proposals for such an alliance with Germany had been offered by Enver Pasha and Sait Halim Pasha, the Grand Vizier, to the Germans already on 22-23 July 1914 , and there must have been negotiations about it preceding these dates. At that time, however, von Wangenheim considered the move premature. Robert J. Kerner, 'Russia, the Straits, and Constantinople, 1914-1915', The Journal of Modern History (Chicago), Vol.I (1929), pp.403-4. Only three days after the signing of the Ottoman-German Alliance, Enver Pasha negotiated with the Russian military attache Leont'ev as to the possibility of an Ottoman-Russian alliance. Akdes Nimet Kurat, Türkiye ve Rusya (Ankara, 1970), pp.230-9.

4. Yusuf Hikmet Bayur, Türk Inkalâbı Tarihi, Vol.III, part I (Ankara, 1983), p.202; Liman von Sanders, Türkiye'de Beş Yll (Istanbul, 1968), p.41.

5. Von Sanders, p.41.

6. Cemal Akbay, Birinci Dünya Harbinde Türk Harbi, Vol.I (Osmanl Imparatorluğunun Siyasî ve Askerî Hazırlikları ve Harbe Girişi) (Ankara, 1970), p.279.

7. Joseph Pomiankowski, Der Zusammenbruch des Ottomanischen Reiches. Erinnerungen an die Türkei aus der Zeit des Weltkrieges (Leipzig, 1928), pp.81-82.

8. 'Pallavicini to Berchtold, 2 September 1914', Documents Diplomatiques Secrets Russes, 1914-1917. D'Après les Archives du Ministère des Affaires étrangères a Pétrograd (Paris, 1928), pp.90-1.

9. Akbay, p.84, $455-6$.

10. Ibid., pp.203-4; Documents Diplomatiques Secrets Russes, pp.90-1.

11. Documents Diplomatiques Secrets Russes, 1914-1917, p.94.

12. Kurat, p.241.

13. Smal-Stocki, p.171.

14. Before the First World War, Basok-Melenevs'kyi and his fellow travellers had little to do with Ukrainian nationalist aims. Then, for them, the Ukrainian language could be of importance only so far as it facilitated socialistic propaganda among the Ukrainian peasants. Helga Grebing, 'Österreich-Ungarn und die "Ukrainische Aktion" 1914-18', Jahrbücher für Geschichte Osteuropas (Munich), Vol.7, No.3 (1959), 278. In fact, Basok-Melenevs'kyi was the leader of that group of the Ukrainian Revolutionary Party which advocated a general democratization in the Russian Empire and opposed autonomy for Ukraine. After the Congress of the Party, Basok-Melenevs'kyi and his followers split from it, and, under the name Spilka, they joined the Russian Social-Democratic Workers' Party. The Spilka, which believed that national oppression would become a thing of the past in the general democratization in the Russian Empire, soon dissolved in the Russian organization. Oleh Semenovych Pidhainy, The Formation of the Ukrainian Republic (Toronto-New York, 1966), p.27.

15. 'Provisorischer Bericht über die Tätigkeit des Bundes zur Befreiung der Ukraina für die Zeit September-Dezember 1914. Wien, den 14. Dezember 1914', Ereignisse in der Ukraine 1914-1922 deren Bedeutung und historische Hintergrïnde, Vol.I (Philadelphia, PA, 1966), pp.175-177.

16. Jerry Hans Hoffman, 'The Ukrainian Adventure of the Central Powers, 1914-1918', Unpublished Ph. D. Dissertation, University of Pittsburgh, 1967, pp.58-9.

17. Grebing, p. 280 .

18. Ibid., p.279; 'Provisorischer Bericht über die Tätigkeit des Bundes zur Befreiung der Ukraina für die Zeit September-Dezember 1914. Wien, den 14. Dezember 1914', pp.177-8. 
19. 'Provisorischer Bericht über die Tätigkeit des Bundes zur Befreiung der Ukraina für die Zeit September-Dezember 1914. Wien, den 14. Dezember 1914', p.178.

20. 'Pallavicini to Hoyos, 2 October 1914', Ereignisse in der Ukraine 1914-1922 deren Bedeutung und historische Hintergründe, Vol.I, p.146.

21. 'Hoyos to Pallavicini, 4 October 1914', ibid., pp.146-7.

22. 'Hoyos to Pallavicini, 9 October 1914', ibid., p.147.

23. Hoffman, pp.59-60.

24. Grebing, p.281. Count Stanislaw Szeptycki was the brother of the Archbishop of the Ruthenian Church in Lemberg (Lviv). Pomiankowski, p.82.

25. 'Provisorischer Bericht über die Tätigkeit des Bundes zur Befreiung der Ukraina für die Zeit September-Dezember 1914. Wien, den 14. Dezember 1914', p.178. As of by mid-Dezember 1914, the ULU group in Istanbul consisted of Mariyan Basok-Melenevs'kyi, Peter Bendzia, Mykola Ryshyi, Peter Dyatliv, Georgii Koval'nyi, Oleksander Pochatok, Isaak Yunak, and Boris Lizovyk. All were originally from the Russian Ukraine. Ibid., p.189.

26. 'Private letter from Hoyos to Hranilovic, 8 November 1914', Ereignisse in der Ukraine 1914-1922 deren Bedeutung und historische Hintergründe, Vol.I, pp.144-5.

27. Ibid., p.145.

28. 'Private letter from Hoyos to Fischer, 13 November 1914', Ereignisse in der Ukraine 1914-1922 deren Bedeutung und historische Hintergründe, Vol.I, p.150.

29. 'From the Imperial and Royal Foreign Office to Pallavicini, 13 November 1914', Ereignisse in der Ukraine 1914-1922 deren Bedeutung und historische Hintergründe, Vol.I, p.153.

30. 'Private Letter from Hoyos to Hranilovic, 14 November 1914', Ereignisse in der Ukraine 1914-1922 deren Bedeutung und historische Hintergründe, Vol.1, pp.151-2.

31. 'From Hoyos to Pallavicini, 16 November 1914', Ereignisse in der Ukraine 1914-1922 deren Bedeutung und historische Hintergründe, Vol.I, p.154.

32. 'From Pallavicini to Hoyos, 16 November 1914', Ereignisse in der Ukraine 1914-1922 deren Bedeutung und historische Hintergründe, Vol.I, pp.154-5.

33. 'Private Letter from Hoyos to Hranilovic, 19 November 1914', Ereignisse in der Ukraine 1914-1922 deren Bedeutung und historische Hintergründe, Vol.I, p.156.

34. 'Private Letter from Hoyos to Palavicini, 19 November 1914', Ereignisse in der Ukraine 1914-1922 deren Bedeutung und historische Hintergründe, Vol.I, pp.158-9.

35. 'Telegram of the Imperial and Royal army Supreme Command, 19 November 1914', Ereignisse in der Ukraine 1914-1922 deren Bedeutung und historische Hintergrïnde, Vol.I, p.159.

36. Pomiankowski, pp.82-3.

37. 'Imperial and Royal Army Supreme Command, 19 November 1914', Ereignisse in der Ukraine 1914-1922 deren Bedeutung und historische Hintergründe, Vol.I, p.159.

38. 'From Hranilovic to Hoyos, 21 November 1914', Ereignisse in der Ukraine 1914-1922 deren Bedeutung und historische Hintergründe, Vol.I, p.157.

39. Hoffman, p.62.

40. 'From the Imperial and Royal Foreign Office to Pallavicini and Hohenlohe, 20 November 1914', Ereignisse in der Ukraine 1914-1922 deren Bedeutung und historische Hintergründe, Vol.I, p.168.

41. During the first week of November 1914, the principal task of the Ottoman navy was determined as, first, protecting, and keeping open, the Black Sea (Istanbul) Strait, second, securing the naval transportation to Istanbul from Zonguldak (where the main coal mines were located) and from Romania and Bulgaria. So long as these tasks were fulfilled, the bombardment of the Russian shores and harassment of the Russian intercoastal tranportation were also considered. In any case, it was recognized that the Russian Black Sea Fleet could still constitute a serious threat to the Ottoman transportation, and thus any large-scale landing operations on the Russian shores were definitely ruled out. Saim Besbelli, Birinci Dïnya Harbinde Tïrk Harbi, Vol.VIII, Deniz Harekâtı (Ankara, 1976), p.79.

42. [Hermann] Lorey, Türk Sularında Deniz Hareketleri (Istanbul, 1936), p.154; Karl Dšnitz, 'Midilli', in Th. Kraus - Karl Dönitz, Die Kreuzerfahrten der Goeben und Breslau (Berlin, 1933), p.170.

43. Skoropys-Joltuchowskyj, 'Über die “Konstantinopler Aktion,' die rolle der ukrain. 
Intelligenz in der russ. Ukraine und Stellungnahme zur eventuellen verlegung des Sitzes des Präsidiums des Bundes z. B. d. U. nach Konstantinopel, 20 Dezember 1914', Ereignisse in der Ukraine 1914-1922 deren Bedeutung und historische Hintergründe, Vol.I, p.191.

44. Ibid., p.192.

45. Fedyshyn, p.36.

46. Ibid.

47. Skoropys-Joltuchowskyj, pp.194-5.

48. Ibid., p.192.

49. Fedyshyn, p.36.

50. 'Provisorischer Bericht über die Tätigkeit des Bundes zur Befreiung der Ukraina für die Zeit September-Dezember 1914. Wien, den 14. Dezember 1914', p.182.

51. Evhen Onats'kyi, 'Talaat Mehemed Bey', Ukrayins'ka Mala Entsyklopediia (Buenos Aires, 1963), p.1873. This source omits the name of Basok-Melenevs'kyi in the ULU delegation received by Talât Bey on 9 November 1914. Nevertheless, since Basok-Melenevs'kyi was the leader of the ULU mission in Istanbul then, and that other sources corroborate the existence of a reception by Talât Bey of Basok-Melenevs'kyi some time in November 1914, almost certainly the latter must be included in the delegation to Talât Bey on 9 November 1914. See, 'From Pallavicini to Berchtold, 1 Dezember 1914', Ereignisse in der Ukraine 1914-1922 deren Bedeutung und historische Hintergrïnde, Vol.I, p.169; and SkoropysJoltuchowskyj, p.191.

52. Onats'kyi, p.1873.

53. 'La question ukrainienne. Déclarations de Talaat bey', Jeune Turc (Istanbul), 24 November 1914. See also, 'From Pallavicini to Berchtold, 1 Dezember 1914 (Supplement)', pp.169-70.

54. Skoropys-Joltuchowskyj, p.191.

55. 'Provisorischer Bericht über die Tätigkeit des Bundes zur Befreiung der Ukraina für die Zeit September-Dezember 1914. Wien, den 14. Dezember 1914', p.177.

56. '“Ukrayna' İstiklâli İçin', Tasfir-i Efkâr (Istanbul), 7 [20] October 1914.

57. 'From Pallavicini to Berchtold, 22 Ekim 1914', Ereignisse in der Ukraine 1914-1922 deren Bedeutung und historische Hintergründe, Vol.I, pp.147-148.

58. 'Ukrayna'da Harekât-1 İhtilâliyye Terakkî Ediyor', Tanin (Istanbul), 13 Dec. 1914.

59. 'Ukraynalıların Mukarrerâtı', Tanin, 29 October 1914.

60. 'Provisorischer Bericht über die Tätigkeit des Bundes zur Befreiung der Ukraina für die Zeit September-Dezember 1914. Wien, den 14. Dezember 1914', pp.178 and 187. The texts of these appeals were published in Vistnyk Soiuza dlya Vyzvolennya Ukrayiny, the biweekly organ of the ULU in Vienna. lbid., p.174.

61. Ibid., p.186. I was unable to locate this booklet in Turkish, if it was ever actually published.

62. Ibid., p.178.

63. Ibid., p.173.

64. Ibid., p.188.

65. Ibid., p.178.

66. Ukrayna, Rusya ve Türkiye (Makaleler Mecmuasi) (Istanbul, 1915).

67. 'Nâşirler Tarafindan', Ukrayna, Rusya ve Türkiye (Makaleler Mecmuast), p.3.

68. Longin Tsehels'kyi, 'Ukrayna ve Türkiye', Ukrayna, Rusya ve Türkiye (Makaleler Mecmuast), pp.12-13.

69. 'Ukrayna Cemiyet-i İstihlâsiyyesi'nin Türk Milleti'ne Hitâbesi', Ukrayna, Rusya ve Türkiye (Makaleler Mecmuasi), pp.60-2.

70. Ibid., pp.62-3.

71. Hoffman, pp.89-90.

72. Six (all?) of the members of the 'Ukrainian Committee' residing in Istanbul by early 1918 were identified as such: Yurii Menkin (28, born in Kharkov, electirician), Ivan Mikhailov (33, born in Sevastopol, electrician), Marko Yashin (29, born in Kerç, merchant), Aleksandr Dimo (35, born in Orgiev, agrarian engineer), Yurii Romanenko (31, born in Lodz, agrarian engineer) and Aleksandr Gulotov (31, born in Kiev, agrarian engineer). The Special Organization organized their return to the Ukraine in early 1918. Archives of the Turkish General Staff Directorate of Military History and Strategical Studies, Ankara (hereafter ATASE Archives), First World War Collection, K: 332, D: 1332, nos. 3, 3-1, 3-2, 3-3, 3-4, 
and 3-5.

73. The presence of two Ottoman passports for Aleksandr Gulotov and Aleksandr Dimo (both issued in Istanbul, in 27 June 1917) in the files of the Ottoman intelligence service testify to this practice. The passports are issued for travel to Stockholm via Bulgaria, Austria and Germany. However, the fact that they do not bear any visa stamps, as well as they still remain among the Ottoman official files, may attest that they were never actually used. ATASE Archives, First World War Collection, K: 332, D: 1332, nos. 2-7 and 2-8.

74. ATASE Archives, First World War Collection, K: 332, D: 1332, nos. 3, 3-1, 3-2, 3-3, 3-4, and $3-5$.

75. V. Oreletsky, 'Ukraine and Turkey', The Ukrainian Review, Vol.IV, No.2 (Summer 1957), p.23. 